\title{
ILMU MUKHTALIF AL-HADIS
}

(Tinjauan Epistemologi)

Oleh: Nurul Hakim

\begin{abstract}
Hadith is positioned as a source of Islamic law after the Qur'an. Therefore, every Muslim should understand the hadith well. However, attempts to understand hadith are very difficult. Moreover, hadith that are contradict with other hadith. To understand hadith which is considered contradict to other hadith, the scholars make a discipline called mukhtalif al-hadis ${ }^{\circ}$. This science is understood as: 1) there is a contradiction that involves two hadiths that are equal (sahih) or with the Qur'an, mind, history, or science and science of knowledge, 2) outward contradiction, 3) the contradiction was solved by using a certain method. With regard to epistemology, there are two sources used in the science of mukhtalif alhadis , asbab al-wurud and ijtihadi. In addition, there are five methods of dispelling the contradiction of a hadith namely, al-jam' wa al-taufiq, al-tarjih, nasikh-mansukh, tawaqquf, and takwil. And in determining the truth of science, correspondence theory is used in hadiths that use asbab al-wurud as the source and theory of coherence used in hadiths that make ijtihädi (science) as the source.
\end{abstract}

\section{Keywords: mukhtalif al-ḥadis, epistemology}

\section{A. Pendahuluan}

Salah satu kenyataan yang tidak dapat dibantah lagi adalah keberadaan hadis-hadis yang tampak saling bertentangan atau yang sering disebut dengan hadis-hadis mukhtalif. Terdapat beberapa hadis Nabi yang satu dengan yang lainnya kelihatan seperti kontradiktif, tidak saling mendukung. Ada juga hadishadis yang berlawanan dengan rasio atau akal sehat manusia dan ilmu pengetahuan. Banyak di antara umat Islam yang terburu-buru menolak hadis yang tampak bertolak belakang. Padahal jika dicermati dan dilihat lebih jauh, hadishadis tersebut, bisa jadi memiliki konteks atau historisitas tersendiri. Sehingga 
tidak seharusnya dibenturkan secara vis a vis dengan hadis yang lain. Para ulama hadis telah merumuskan sebuah disiplin ilmu yang membahas khusus dalam permasalahan ini, yakni yang dikenal dengan ilmu mukhtalif al-ḥadï. Secara sederhana ilmu ini berfungsi untuk "mengompromikan" hadis-hadis yang tampak bertentangan dengan menggunakan metode tertentu.

Dalam tulisan yang sederhana ini, penulis akan mencoba memperbincangkan lebih jauh tentang ilmu mukhtalif al-hadìi dalam bingkai epistemologi. Hal ini mengandung maksud bahwa penulis akan lebih banyak membicarakan ilmu mukhtalif al-ḥadis sebagai sebuah disiplin ilmu yang memiliki konstruk pengetahuan, baik berupa sumber, bangunan, metode, dan validitas keilmuan. Sudah barang tentu tulisan ini bukanlah penelitian yang komprehensif terkait dengan tema ini. Akan tetapi lebih merupakan media pembelajaran bagi penulis dan kajian yang bersifat pengenalan awal untuk memberikan "pancingan" akademik bagi para pembaca yang hendak melakukan kajian lebih lanjut. Dengan penuh kerendahan hati penulis memohon maaf atas kekurangan yang terdapat di dalam tulisan ini. Oleh karena itu, penulis sangat berharap kritik dan saran yang membangun dari para pembaca.

\section{B. Ilmu Mukhtalif al-Hadis: Apa dan Bagaimana}

Mukhtalif al-hadìं terdiri dari dua suku kata, yakni mukhtalif dan al-ḥadï. Secara etimologi, mukhtalif adalah ism fa'il dari kata ikhtalafa-yakhtalifu yang berarti bertentangan atau berlawanan (A.W. Munawwir, 1997: 362). Sedangkan al-ḥadis adalah sebagaimana banyak dipahami oleh banyak orang, yakni titah dan 
tindak-tanduk yang disandarkan kepada Rasulullah. Dengan demikian secara bahasa dapat dikatakan bahwa hadis mukhtalif adalah hadis (titah dan tindaktanduk Nabi) yang satu sama lainnya bertentangan atau berselisih. Para ulama ahli hadis kemudian mendefinisikan mukhtalif al-hadï dengan hadis-hadis Nabi yang tampak saling bertentangan satu sama lain (Abdul Mustaqim, 2008: 84; Fatchur Rahman, 1974: 335).

Berkenaan dengan mukhtalif al-hadis, beberapa ulama mencoba membuat definisinya, di antaranya; al-Hākim al-Naisābūri (w. 405 H) menulis dalam bukunya, Ma 'rifat 'Ulum al-Hadìis, sebuah karya yang dianggap sebagai literatur pertama dan tertua dalam 'ulum al-ḥadis:

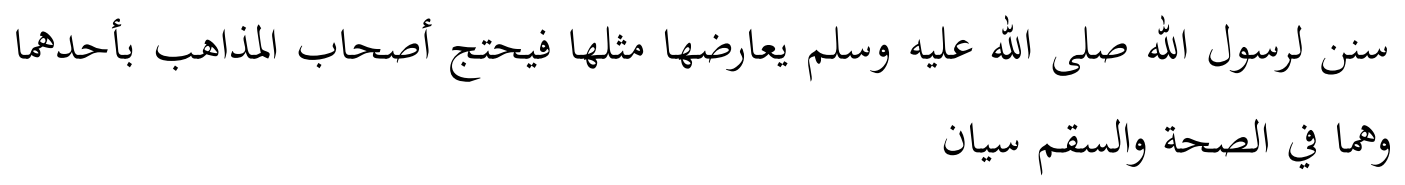

Artinya: "Sunnah-sunnah Rasulullah SAW yang bertentangan dengan sesamanya, lalu para ulama memakai salah satunya sebagai dalil, di sisi lain keduanya setara dalam kesahihan dan kelemahannya." (Al-Imām alḤākim Abi 'Abd Allāh Muḥammad bin'Abd Allāh al-Ḥāfiz alNaisābūri, 1977: 122).

Sementara menurut Nūr al-Din 'Itr, hadis-hadis mukhtalif ialah hadis-hadis yang secara lahiriah bertentangan dengan kaidah-kaidah yang baku, sehingga mengesankan makna yang batil atau bertentangan dengan naṣ-naṣ syara' yang lain (Nūr al-Dỉn'Itr, 1997: 177). Dalam hal ini Nūr al-Dỉn 'Itr memahami mukhtalif hadis dalam lingkup yang lebih luas, tidak hanya terbatas pada hadis dengan hadis, tetapi juga hadis dengan dalil syara' yang lain. Hal senada juga diungkapkan oleh Abdul Mustaqim bahwa semestinya pengertian hadis mukhtalif 
tidak hanya terbatas pada sesama hadis, melainkan harus dikembangkan, seperti pertentangan dengan al-Qur'an, akal, sejarah, atau ilmu pengetahuan dan sains pengetahuan (Abdul Mustaqim, 2008:84).

Sedangkan untuk ilmu mukhtalif al-ḥadī', 'Ajajj al-Khațib mendefinisikannya sebagai ilmu yang mengkaji perihal hadis-hadis yang saling tampak bertentangan dan kemudian menghilangkannya atau mengompromikan keduanya, dan juga membahas tentang hadis-hadis yang sulit dipahami lalu kemudian menghilangkan dan menjelaskan hakikat kesulitan tersebut (Ajaj alKhāṭib, 1989: 283). Subhi Șāliḥ juga memberikan definisi:

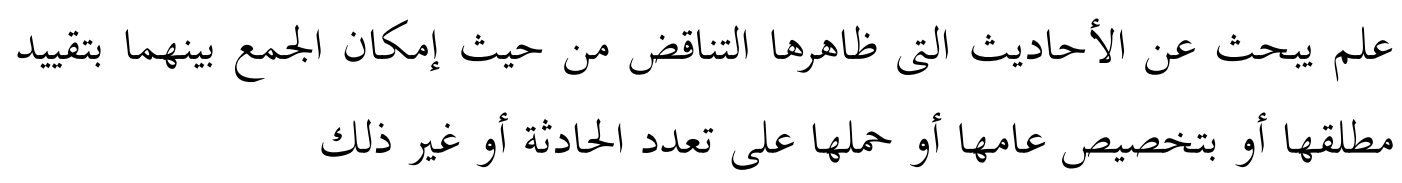

Artinya: "Ilmu yang membahas hadis-hadis yang menurut lahirnya saling bertentangan yang kemudian dapat dikompromikan dengan cara mentaqyid kemutlakannya, atau mentakhșiṣ keumumannya, atau menganggap terjadinya pengulangan peristiwa."

Dari seluruh definisi yang ditawarkan di atas, penulis lebih cenderung pada pendapat yang mengartikan mukhtalif al-ḥadis dalam lingkup yang lebih luas, tidak hanya terbatas pada internal hadis. Karenanya dapat ditarik beberapa kesimpulan terkait dengan definisi mukhtalif al-hadi $\vec{i}$, antara lain; 1) terjadi pertentangan yang melibatkan dua hadis yang sederajat (sahihh) atau dengan alQur'an, akal, sejarah, atau ilmu pengetahuan dan sains pengetahuan, 2) pertentangan bersifat lahiriah, 3) pertentangan itu diselesaikan dengan metode tertentu. 


\section{Konstruksi Epistemologi Ilmu Mukhtalif al-Hadis}

\section{Sejarah Keilmuan Mukhtalif al-Hadis}

Kajian teoritis tentang kontradiksi yang ada dalam hadis-hadis Nabi SAW sudah dimulai sejak abad kedua hijriah. Sebagaimana dicatat al-Suyūtị, buku yang pertama kali membahasnya sebagai kajian yang mandiri adalah Ikhtiläf al-Hadis karya al-Imām al-Syāfí̄i (w. 204 H) (Al-Syāfiii, 1986). Dalam tema yang sama, alImām Ibn Qutaibah (w. 276 H) tampil dengan karyanya Ta'wil Mukhtalif al-Hadìं (Abū Muhammad'Abd Allāh bin Muslim bin Qutaibah, 1995), yang berusaha mempertahankan akidah melalui pendekatan hadis sebagai pengkayaan sekaligus alternatif bagi perspektif yang berkembang luas saat itu dalam memahami problem-problem teologis yang sering kali dimonopoli kelompok kalam, tasawuf, dan filsafat. Kajian mukhtalif al-hadïs juga diperkaya dengan kehadiran Musykil al-Asar karya Abū Ja'far al-Ṭahawi (w. $321 \mathrm{H}$ ), seorang ahli fikih, pakar hadis, dan mufasir yang dipercaya sebagai pendiri aliran Mazhab Tahawiyyah, salah satu sekte dalam rumpun Sunni. Berikutnya, Ibn Furak (w. 406 H) menghadirkan master piece-nya yang berjudul Musykil al-Hadï.

Melalui karyanya terlihat secara jelas di mana posisi al-Syäfi $i$, di mana ia mencoba membela eksistensi hadis sebagai bagian dari syariat. Dalam bangunan

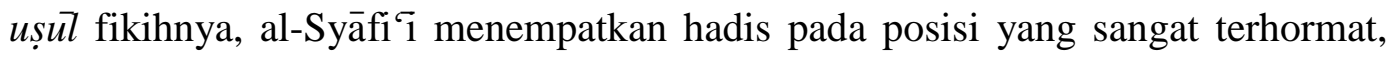
tepat satu tingkat di bawah al-Qur'an sebagai sumber ajaran Tuhan yang paling otentik dan otoritatif. Di satu sisi, al-Syāfíi dalam menegaskan eksistensi hadis, lebih condong untuk menyerang kepada orang-orang yang anti terhadap hadis, dan begitu pula untuk membangun perspektif (ideologis) fikih. Hampir seluruh contoh 
yang dibawakan al-Syāfi i dalam karya ini memiliki dimensi hukum fikih. Terdapat lima bagian (juz) dalam kitab Ikhtiläf al-Hadìi ini, di mana dalam setiap bagian al-Syāfi $i$ mencoba menyelesaikan hadis-hadis yang menurut pengertian lahiriahnya bertentangan satu sama lain. Dan semua terkait dengan persoalan hukum.

Ini berbeda dengan yang apa yang melatari kemunculan Ta'wil Mukhtalif al-Hadìi di tangan Ibn Qutaibah (w. 276 H). Sekalipun hidup pada masa yang sama, namun memiliki proyek ideologis yang sedikit berbeda. Hal ini terkait lawan yang dihadapi Ta'wil Mukhtalif al-Hadï. Mereka adalah kelompok kalam, yang selain meninggikan rasionalitas Yunani di satu sisi, juga menjatuhkan kewibawaan "tradisi” yang menjadi sumber ajaran kaum muslimin. Ibn Qutaibah menulis:

$$
\begin{aligned}
& \text { وقد تدبرت -رحمك الله-كام العايبين و الزارين فوجدةم يقولون على الله مالا يعلمون } \\
& \text { ويعيبون الناس بما يأتون ويبصرون القذى في عيون الناس وعيوهم تطرف على الأجذاع } \\
& \text { ويتهمون غيرهم في النقل ولا يتهمون آراءهم في التأويل. ومعاني الكتاب والحديث وما } \\
& \text { أودعاه من لطائف الحكمة وغرائب اللغة لا تدرك بالطفرة والتولد والعرض والجوهر } \\
& \text { والكيفية والكمية والأينية. ولو ردوا المشكل منهما إلى أهل العلم بهما وضح لهم المنهج } \\
& \text { واتسع لهم المخرج ولكن يمنع من ذلك طلب الرياسة وحب الأتباع واعتقاد الإخوان } \\
& \text { بالمقالات. والناس أسراب طير يتبع بعضها بعضا. }
\end{aligned}
$$

Artinya: "Aku telah menelaah pendapat-pendapat ahli kalam. Aku menjumpai mereka berkata tentang Allah dengan sesuatu yang mereka tidak tahu, dan menebar kekacauan kepada masyarakat dengan segala apa yang mereka bawa. Mereka melihat di mata masyarakat terdapat kotoran, padahal mata mereka tertusuk pohon kurma. Mereka menuduh selainnya telah melakukan kesalahan dalam menukil informasi dari Nabi, tetapi mereka tidak curiga sama sekali pada pendapatnya dalam menakwilkan dan pemahaman terhadap ayat-ayat al-Qur'an, hadis- 
hadis Nabi, kandungan kebajikannya, serta keindahan bahasanya yang tentu saja tidak dapat diperoleh melalui lompatan (tanpa penahapan), teori tawallud, 'arad (sifat), jauhar (substansi wujud), kaifiyyah (proses), kammiyyah (kuantitas), ainiyyah (ruang). Andai saja mereka mengembalikan persoalan itu kepada orang yang berilmu, maka teranglah jalan dan lapanglah pintu keluar bagi mereka. Tetapi nafsu berkuasa dan memperoleh banyak pengikut telah menguasai mereka dan keyakinan terhadap perkataan-perkataan mereka. Dan manusia pun tersesat ketika mengikuti mereka." (Abū Muhammad'Abd Allāh bin Muslim bin Qutaibah, 1995: 24-25).

Lalu kemudian datang al-Ṭaḥawi (w. $321 \mathrm{H}$ ) dengan karyanya, Musykil alAsar. Sebagaimana dapat dilihat pada alasan penulisan karya tersebut, di mana ia berkata:

$$
\begin{aligned}
& \text { وإين نظرت في الآثار المروية عنه صلى الله عليه وسلم بالأسانيد المقبولة التى نقلها ذوو } \\
& \text { التثبت فيها والأمانة عليها وحسن الأداء لما فوجدت فيها أشياء محا يسقط معرفتها } \\
& \text { والعلم بما فيها عن أكثر الناس فمال قلى إلى تأملها وتبيان ما قدرت عليه من مشكلها } \\
& \text { ومن استخراج الأحكام التى فيها ومن نفى الاحالات عنها وأن أجعل ذلك أبوابا... }
\end{aligned}
$$

Artinya: "Aku melihat asar-asar yang bersumber dari Nabi SAW telah disampaikan dengan sanda-sanad yang diterima, dinukil oleh orangorang yang serius menelitinya, penuh tanggung jawab, dan menggunakan metode yang baik. Aku mendapati banyak yang luput dan tidak diketahui kebanyakan orang. Hatiku tergerak untuk merenunginya, menjelaskan apa yang janggal sesuai kadar kemampuanku, mengeluarkan hukum yang dikandungnya, dan menegasikan ketidak-mungkinan yang ada di dalamnya, dan mengkajinya secara perbab..." (Abū Jảar al-Ṭaḥawi, 1994: 6).

Al-Ṭahawi mengawali dari ketidaklengkapan dan ketidaksempurnaan pada kajian hadis. Pada abad keempat hijriah perdebatan kalam masih terlalu ramai. Tokoh-tokoh yang memiliki keterkaitan "ideologis" dengan ahli hadis, menggunakan cara yang beranekaragam untuk menolak serangan musuhmusuhnya. Tentu saja seluruh kekayaan khazanah yang ada merupakan warisan era tadwin pada dua abad sebelumnya. Di mana dalam formulasinya yang telah 
mapan, ilmu-ilmu yang berkembang pada abad ini menjadi kelanjutan dari problem-problemnya. Selain warisan ilmu, juga warisan problem-problem yang banyak ditunggangi aspek ideologis.

Dua abad setelahnya, muncul kitab Musykil al-Hadisं karya Ibn Furak (w. $406 \mathrm{H})$ yang menggunakan pendekatan yang sama dengan yang dipakai Ibn Qutaibah. Sekalipun dengan kondisi psikologi masa, namun hal ini sekaligus memberi tantangan yang berbeda. Karena pada abad tersebut, mazhab pemikiran kaum muslimin telah benar-benar mencapai tahapnya yang stagnan. Kaum rasionalis tidak terlalu kuat, jika dibandingkan dengan sebelumnya. Yang justru menguat adalah gerakan literalis ahli hadis yang hendak merespon rasionalisme Mu'tazilah yang masih memiliki pengaruh epistemis dalam lingkungan muslimin.

\section{Sumber Keilmuan}

Membicarakan hadis, dalam hal ini hadis mukhtalif, tidak terlepas dari hal periwayatan. Karena memang hadis itu sendiri diperoleh dari jalur periwayatan dari masa Rasulullah hinggga para mukharrij hadis. Adalah niscaya untuk mengetahui jalur periwayatan sebuah hadis, terlebih apabila adanya pertentangan antar hadis. Untuk mengetahui apakah sebuah hadis bertentangan dengan hadis lain, atau akal, atau yang lainnya, penulis merangkum, setidaknya, ada dua poin, yakni:

a. Asbab al-Wurūd 
Asbab al-wurüd menjadi hal yang sangat penting ketika mendiskusikan tentang hadis-hadis mukhtalif. Karena ia menjadi salah satu cara yang paling sering digunakan untuk mengetahui apakah ada pertentangan di dalam sebuah hadis. Asbab al-wurūd di sini bisa berupa riwayat (mikro) atau ijtihad (makro) (Lenni Lestari, 2012). Berikut adalah beberapa contoh mengenai hal ini; pertama, tentang nikah mut'ah. Terdapat dua hadis tentang nikah mut'ah yang memiliki derajat yang sama yang tampak saling bertentangan dan berselisih. Pertama adalah hadis riwayat Muslim (Muslim, 2006: 632):

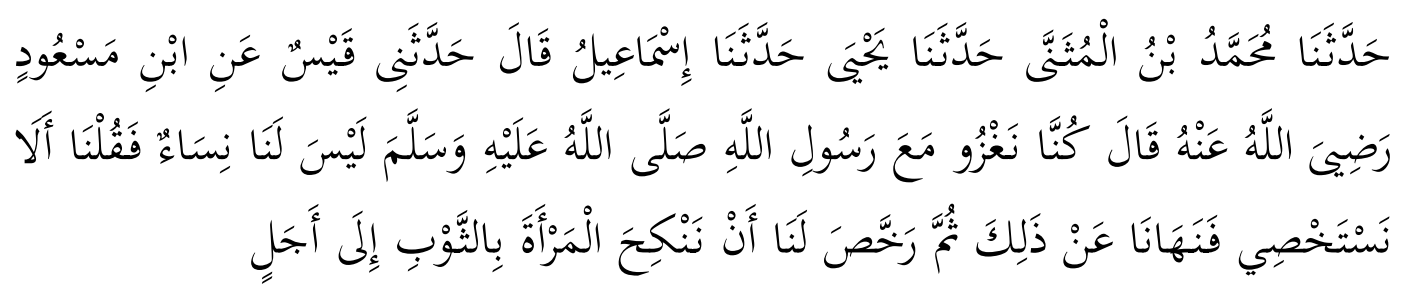

Artinya: "Telah menceritakan kepada kami Muhammad bin Abdullah bin Numair Al Hamdani telah menceritakan kepada kami bapakku dan Waki' dan Ibnu Bisyr dari Isma'il dari Qais ia berkata, saya mendengar Abdullah berkata; Kami pernah berperang bersama Rasulullah SAW tanpa membawa isteri, lalu kami berkata, "Apakah sebaiknya kita mengebiri kemaluan kita?" Rasulullah SAW melarang kami berbuat demikian, dan beliau memberikan keringanan pada kami untuk menikahi perempuan sampai pada batas waktu tertentu dengan mas kawin pakaian."

Dan yang kedua adalah hadis riwayat Bukhāri:

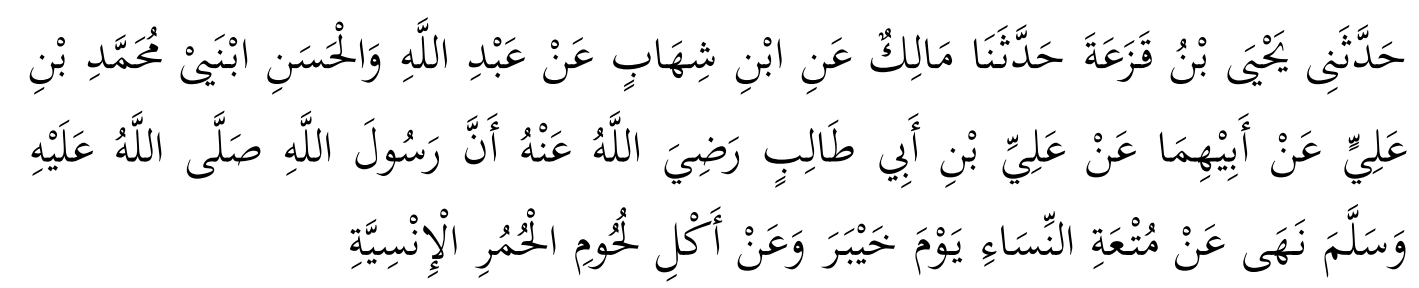

Artinya: "Telah menceritakan kepadaku Yahya bin Qaza'ah telah menceritakan kepada kami Malik dari Ibnu Syihab dari Abdullah dan Al Hasan, dua anak Muhammad bin 'Ali dari Bapak keduanya dari 'Ali bin Abu Thalib 
RA bahwa Rasulullah SAW melarang nikah mut'ah (perkawinan dengan waktu terbatas semata untuk bersenang-senang) dan melarang makan daging keledai jinak pada perang Khaibar." (Abū 'Abd Allāh Muhammad bin Ismā'il bin Ibrāhim bin al-Mughỉah al-Ju'fiy alBukhāriy, 2006: 1036).

Hadis yang pertama merupakan hadis yang membolehkan nikah mut'ah dan hadis yang kedua adalah hadis yang melarang nikah mut'ah. Lalu, bagaimana memahami kedua hadis yang tampak saling bertentangan ini? Hal ini akan mudah dipahami jika umat Islam memahami konteks atau situasi ketika kedua hadis ini muncul (baca: asbab al-wurūd). Dapat dilihat pada hadis pertama bahwa alasan kenapa ketika itu dibolehkan melaksanakan nikah mut'ah ialah karena pada saat itu dalam keadaan perang (khaibar) yang jauh dari istri, sehingga para sahabat yang ikut perang merasa sangat berat. Selain itu, pada masa itu masih dalam masa peralihan dari kebiasaan zaman jahiliah. Jadi wajar jika kemudian mereka para sahabat diberikan keringanan (rukhșah). Tetapi setelah alasan-alasan di atas tidak ada lagi, Rasulullah kemudian melarang nikah mut'ah sebagaimana sabdanya pada hadis yang kedua.

Di sini tampak bahwa sebenarnya kedua hadis di atas tidaklah bertentangan melainkan bahwa kedua hadis di atas muncul dalam konteks yang berbeda. Yang pertama datang di awal dan yang kedua datang kemudian. Hadis yang pertama menjadi tidak berlaku lagi (mansukh) ketika hadis kedua sudah ada (näsikh). Dan yang digunakan adalah hadis yang kedua. Dengan demikian dapatlah dipahami bahwa asbab al-wurüd sangatlah penting di dalam memahami sebuah hadis, terlebih ketika hendak mengompromikan hadis-hadis yang tampak kontradiktif. 
Kedua, berkenaan dengan daging kurban. Pada suatu saat datang waktu kurban, Rasulullah menyaksikan banyak orang miskin yang datang ke kota Madinah untuk mendapatkan bagian daging kurban. Beliau memahami bahwa daging yang ada di kota Madinah tidak sebanding dengan jumlah orang miskin yang datang ketika itu. Oleh sebab itu, untuk menyikapi hal ini, Rasulullah melarang penduduk setempat untuk menyimpan daging kurban lebih dari tiga hari.

Dan pada saat itu tidak ada satupun sahabat yang bertanya dan memprotes Nabi. Mereka hanya "sami 'nā wa aṭa 'na" kepada Rasulullah meskipun tidak paham dan mengerti apa yang diinginkan oleh Rasulullah atas larangannya itu. Akan tetapi, ketika kesadaran untuk berkurban semakin tinggi dan bertambah serta orang yang berkurban semakin banyak, Nabi kemudian mencabut larangan ini. Ketika larangan dicabut, barulah Rasulullah memberitahukan alasan mengapa dahulu beliau mengeluarkan larangan untuk menyimpan daging lebih dari tiga hari. Alasan yang paling utama, sebagaimana dilansir oleh Daniel Djuned, adalah bahwa banyaknya orang miskin luar kota yang datang ke Madinah. Andai saja orang-orang Madinah dibolehkan untuk menyimpan daging kurban sebanyakbanyaknya lebih dari tiga hari, tentu saja orang-orang luar Madinah tidak kebagian (Daniel Djuned, 2010: 142). Sebagaimana sabdanya; “Aku melarang kalian (menyimpan daging kurban lebih dari tiga hari) karena (melihat banyaknya) orang-orang desa yang datang (ke Madinah) pada hari pemotongan hewan kurban, sekarang makanlah (simpanlah).

Dapat dilihat dari dua hadis di atas bahwa yang pertama tampak bertentangan dengan hadis kedua. Yang pertama melarang menyimpan daging 
kurban dan yang kedua membolehkannya. Dengan melihat latarbelakang (baca: asbab al-wurūd), umat Islam (baca: para pembaca hadis) dapat melihat bahwa sebenarnya tidak terjadi pertentangan karena kedua hadis tersebut muncul dalam waktu dan situasi yang berbeda. Hal ini dapat dipahami juga bahwa hadis yang pertama menjadi tidak berlaku (mansukh) dengan adanya hadis yang kedua (nāsikh).

Dari kedua contoh di atas kiranya dapat disimpulkan bahwa asbab al-wurüd adalah niscaya ketika membincangkan tentang hadis-hadis yang bertentangan. Pemahaman yang baik dan benar terhadap konteks kemunculan sebuah hadis akan membawa kepada pemahaman yang tepat pula. Dalam hal mukhtalif al-hadis, maka dengan sendirinya akan diketahui ketidakbertentangan yang pada awalnya tampak bertentangan.

\section{b. Ijtihad}

Pola kedua adalah ijtihad. Penulis cenderung untuk mengatakan ijtihad di sini adalah ilmu pengetahuan. Hal ini sebagaimana diungkapkan oleh Zaghlul alNajjar bahwa ada sejumlah hadis Nabi yang memang secara lahiriah bertentangan dengan ilmu pengetahuan. Dan sebenarnya, berdasarkan penelitiannya, bahwa hadis-hadis tersebut tidaklah berlawanan dengan ilmu pengetahuan. Hanya saja para pembaca hadis belum mampu memahaminya secara tepat dan akurat. Salah satu contoh adalah hadis tentang perintah Rasulullah untuk menenggelamkan lalat yang hinggap di gelas. Berikut adalah redaksi hadis tersebut: 


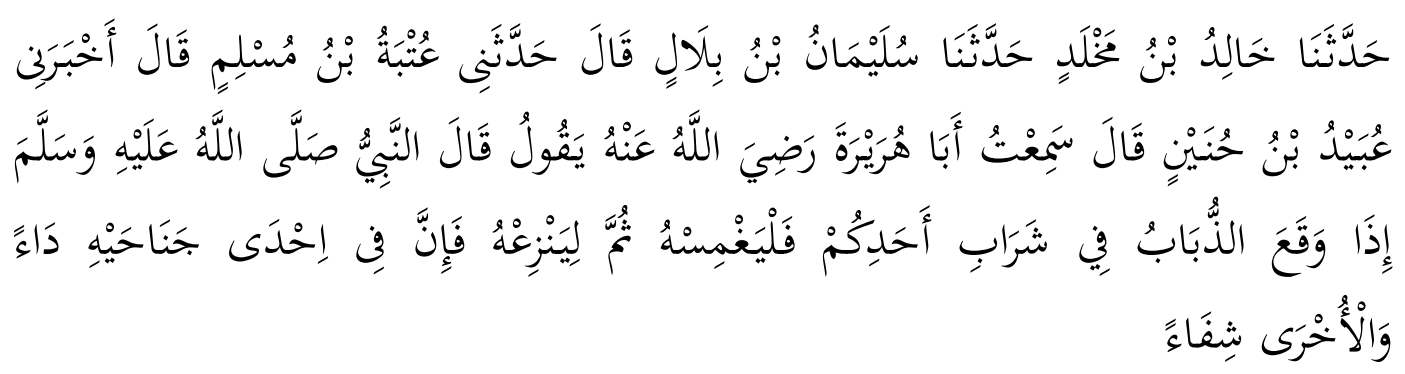

Artinya: "Telah bercerita kepada kami Khalid bin Makhlad telah menceritakan kepada kami Sulaiman bin Bilal berkata; telah bercerita kepadaku Utbah bin Muslim berkata; telah mengabarkan kepadaku Ubaid bin Hunain berkata; saya mendengar Abu Hurairah RA berkata; Nabi SAW bersabda: "Jika ada seekor lalat yang terjatuh pada minuman kalian maka tenggelamkan kemudian angkatlah, karena pada satu sayapnya penyakit dan sayap lainnya terdapat obatnya." (Abū 'Abd Allāh Muḥammad bin Ismā'il bin Ibrāhim bin al-Mughïrah al-Ju'fiy alBukhāriy, 2006: 815).

Sepintas dapat dilihat bagaimana mungkin Rasulullah memerintahkan untuk menenggelamkan lalat ke dalam gelas sedangkan lalat-sebagaimana kebanyakan orang pahami-adalah serangga yang kotor dan penyebar penyakit. Tentu akal manusia_-yang normal—akan menolak dan tidak menerima perintah dari Rasulullah ini. Tetapi kemudian Zaghlul al-Najjar-melalui karyanyamenolak bantahan bahwa hadis Nabi ini bertentangan dengan akal dan teori kesehatan. Menurutnya perintah Rasulullah tersebut, apabila dipahami dengan baik, tidaklah bertentangan dengan akal dan ilmu kesehatan.

Akhir-akhir ini sudah ada penelitian yang mengungkapkan kebenaran hadis Rasulullah di atas. Sebagaimana dilansir oleh Abdul Mustaqim, bahwa sejumlah peneliti di Arab Saudi dan Mesir menemukan sebuah temuan yang berbeda dengan apa yang diperkiran oleh banyak orang. Mereka menyiapkan beberapa bejana yang diisi air, madu, dan juz. Kemudian bejana ini dibiarkan terbuka 
hingga dimasuki lalat. Setelah itu, mereka kemudian membandingkan antara minuman yang hanya dihinggapi oleh lalat dengan minuman yang lalat dibenamkan di dalamnya. Dan hasilnya, dengan menggunakan mikroskop dapat dilihat bahwa minuman yang tidak dibenamkan lalat di dalamnya dipenuhi dengan kuman dan mikroba. Sedangkan minuman yang dihinggapi lalat dan dibenamkan ke dalamnya, justru tidak ditemukan kuman dan mikroba (Zaghlul al-Najjar, 2011: 320).

Upaya di atas menandakan tentang bagaimana upaya yang dilakukan untuk mengungkap misteri-misteri dibalik titah Rasulullah yang secara lahiriah bertentangan dengan akal dan ilmu pengetahuan. Terlepas dari pro-kontra tentang i ‘jaz 'ilmì yang terkandung di dalam hadis Nabi, hasil penelitian ini menunjukkan bahwa pada hakikatnya hadis Rasulullah tidaklah bertentangan dengan akal sehat dan ilmu pengetahuan. Dan upaya ini (ijtihad) adalah salah satu cara untuk memberikan bukti kepada mereka yang menolak hadis-hadis Nabi yang kontradiktif bahwasannya hal itu hanya bersifat lahiriah.

\section{Metode Memahami Hadis Mukhtalif}

Sebelum membahas metode memahami hadis-hadis mukhtalif, kiranya perlu penulis utarakan terlebih dahulu tentang beberapa faktor penyebab hadis-hadis yang tampak saling bertentangan. Sebagaimana disebutkan oleh (Abdul Mustaqim, 2008: 87) setidaknya ada empat faktor: pertama, yang bersumber dari internal hadis itu sendiri. Yakni redaksi hadis yang memang terkesan bertentangan 
atau sulit dipahami. Kedua, yakni yang disebabkan oleh konteks dari sebuah hadis itu muncul. Hal ini bisa berupa kepada siapa Nabi menyampaikan hadis, di mana, dan kapan. Jika ditemukan, maka dengan mengetahui konteksnya maka akan terlihat posisi dari masing-masing hadis tersebut. Ketiga, faktor metodologi, yakni berkenaan dengan cara seseorang memahami hadis. Ada orang yang memahami hadis secara literalis, sehingga ada sebagian hadis dianggap bertentangan dengan hadis yang lain. Dan keempat, faktor ideologi. Hal ini banyak terjadi pada masa awal-awal perkembangan Islam. Hadis dipahami sesuai dengan ideologi atau mazhab tertentu dan menolak hadis-hadis yang secara lahiriah bertentangan dengan ideologi mereka.

Berkenaan dengan metode memahami hadis-hadis mukhtalif, para ulama menawarkan lima metode. Di antaranya, pertama, metode al-jam'wa al-taufī . Maksudnya adalah menggabungkan dua hadis yang tampak saling bertentangan yang memiliki kualitas sama, yakni șaḥih. Bentuk penggabungan ini bisa berupa 'amm dan khașṣ, muțlaq dan muqayyad, dan lain-lain. contoh sederhananya adalah hadis tentang cara wudu Rasulullah. Dalam sebuah hadis yang diriwayatkan oleh al-Syāfíi dari Ibn 'Abbās, bahwa Rasulullah berwudu membasuh muka dan kedua tangannya, serta mengusap kepalanya satu kali. Sementara dalam riwayat al-Syāfi'i lainnya, dari Ușmān bin 'Affān bahwa Rasulullah melakukannya sebanyak tiga kali. Dua hadis ini secara lahiriah tampak bertentangan tetapi sejatinya tidak. Menurut al-Syāfi $\mathfrak{i}$ hadis ini bisa dipahami bahwa membasuh wajah dan kedua tangan, serta mengusap kepada satu kali sudah 
cukup. Sedangkan yang lebih baik adalah tiga kali sebagaimana hadis yang kedua di atas (Al-Syāfîi, 1986:102).

Kedua, metode tarjih. Maksudnya adalah memilih dan mengunggulkan satu di antara hadis-hadis yang tampak bertentangan yang kualitasnya paling baik. Hal ini dilakukan ketika metode yang disebutkan di atas tidak dimungkinkan lagi. Ketiga, metode nāsikh-mansukh. Ini adalah tahap ketiga yang ditempuh ketika dua metode di atas tidak dapat mengatasi hadis-hadis mukhtalif. Metode ini menerapkan prinsip pembatalan salah satu hadis. Caranya adalah dengan melihat mana hadis yang datang lebih dahulu dengan hadis yang datang belakangan. Hadis yang datang belakangan menjadi pembatal (nāsikh) bagi hadis yang datang lebih dahulu (mansukh). Proses naskh hanya dapat terjadi di saat Rasulullah masih hidup. Karena beliau adalah syäri', yang berhak menghapus sebuah syara'. Di antara contoh yang sering didengar adalah tentang ziarah kubur. Bahwa Rasulullah pernah melarang para sahabatnya, terutama perempuan, untuk berziarah kubur. Hal ini karena pada saat itu memang Rasulullah masih dalam proses membentuk akidah dan iman para pemeluk awal Islam. Kenyataan bahwa tradisi meronta-ronta di kuburan adalah hal yang tidak bisa dihindari. Karenanya, untuk menghindari hal-hal yang tidak diinginkan, Rasulullah melarang ziarah kubur. Tetapi kemudian setelah masa suram berlalu dan iman para sahabat semakin kuat, kematian menjadi hal yang bisa dan tidak dikhawatirkan. Pada masa ini, larangan berziarah kubur tidak perlu lagi diteruskan. Rasulullah kemudian membolehkan berziarah kubur. Justru ziarah kubur dianjurkan agar selalu mengingat kematian dan hari pembalasan. 
Keempat, metode tawaqquf. Artinya adalah berhenti. Berhenti dalam artian mendiamkan dan tidak dilanjutkan proses kompromi. Hal ini dilakukan manakala metode nasikh-mansukh tidak dapat mengatasi hadis-hadis yang tampak bertentangan. Lebih jauh bahwa hadis-hadis yang tampak bertentangan tersebut tidak diamalkan sampai ditemukan keterangan tentang hadis manakah yang dapat diamalkan. Dan kelima, metode takwil. Hal ini dilakukan terhadap hadis-hadis yang sudah sampai pada tahap tawaqquf. Dalam hal ini, Abdul Mustaqim menyatakan bahwa metode tawaqquf tidaklah menyelesaikan masalah. Karena mendiamkan dan membiarkan hadis-hadis mukhtalif tanpa dicarikan solusi yang tepat. Oleh sebab itu, teori tawaqquf ini semestinya dipahami sebagai sementara waktu saja sampai ada penjelasan (baca: takwil) terhadap hadis tersebut (Abdul Mustaqim, 2008:98).

\section{Validitas Keilmuan}

Ada beberapa teori untuk menguji kebenaran sebuah ilmu pengetahuan, di antaranya adalah korespondensi (kesesuaian), keherensi (keruntutan), pragmatik, dan beberapa yang lainnya (Ali Mudhofir dan Heri Santoso, 2007: 83-90). Kaitannya dengan ilmu mukhtalif al-hadisं, penulis cenderung untuk memilih teori korespondensi sebagai cara uji kebenarannya. Korespondensi adalah kesesuaian (kecocokan) hal atau pengetahuan yang terdapat dalam pikiran (subjek) dengan kenyataan objektif yang di luar pengetahuan ((Ali Mudhofir dan Heri Santoso, 2007: 83). Misalnya ungkapan "Candi Borobudur terletak di Provinsi Jawa Tengah." Hal ini benar karena sesuai dengan fakta situasi geografis yang dapat 
diamati. Demikian pula dengan ilmu mukhtalif al-hadis yang menjadikan asbab al-wurūd sebagai sumber ilmu pengetahuan, fakta-fakta sejarah dijadikan tolak ukur atas kebenaran dari sebuah riwayat.

Berbeda halnya dengan hadis-hadis yang menggunakan ijtihàd $\bar{i}$ atau ilmu pengetahuan untuk menjawab pertentangan dalam sebuah hadis. Penulis lebih cenderung menggunakan koherensi sebagai teori kebenarannya. Koherensi adalah berhubungan dengan sesuatu idea, prinsip, tatanan, atau konsep yang besifat umum. Ilmu pengetahuan dikatakan benar ketika ia konsisten, tidak mengandung makna yang saling menyisihkan. Seperti pernyataan "bujangan belum menikah" atau "lingkaran berbentuk bulat" (Ali Mudhofir dan Heri Santoso, 2007: 85). Jika ada hadis-hadis yang tampak bertentangan dengan ilmu pengetahuan, dan kemudian ditemukan teori-teori tertentu yang menggugurkan atau menghilangkan pertentangan tersebut, maka hal ini menurut peneliti sejalan dengan prinsip koherensi.

\section{Kesimpulan}

Sekiranya dari pemaparan di atas, dapat ditarik beberapa kesimpulan, di antaranya:

Pertama, inti dari definisi (ilmu) mukhtalif al-ḥadisं adalah 1) terjadi pertentangan yang melibatkan dua hadis yang sederajat (sahih Qur'an, akal, sejarah, atau ilmu pengetahuan dan sains pengetahuan, 2) pertentangan bersifat lahiriah, 3) pertentangan itu diselesaikan dengan menggunakan metode tertentu. 
Kedua, bahwa para ulama telah melakukan kajian secara serius terkait dengan hadis-hadis mukhtalif. Terbukti dari karya-karya yang hingga saat ini

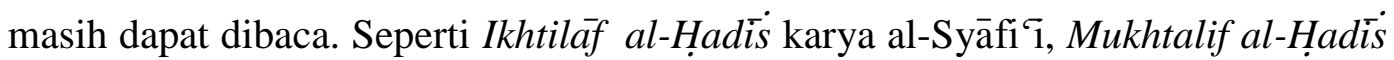
karya Ibn Qutaibah, Musykil al-Asar karya al-Ṭahawi, dan Musykil al-Hadï karya Ibn Furak.

Ketiga, ada dua sumber yang digunakan dalam ilmu mukhtalif al-ḥadis, yakni asbäb al-wurūd dan ijtihad.

Keempat, ada lima metode dalam menghilangkan pertentangan pada sebuah hadis yakni, al-jam' wa al-taufī, al-tarjih̆, näsikh-mansukh, tawaqquf, dan takwil.

Kelima, dalam menentukan kebenaran ilmu pengetahuan, teori korespondensi digunakan pada hadis-hadis yang memakai asbab al-wurüd sebagai sumber dan teori koherensi digunakan pada hadis-hadis yang menjadikan ijtihādi (baca: ilmu pengetahuan) sebagai sumber. 


\section{DAFTAR PUSTAKA}

Ali, Nizar. 2008. Hadis dan Sains: Memahami Hadis-Hadis yang Musykil, t.tp: Teras,

Bukhāriy, Abū 'Abd Allāh Muḥammad bin Ismā '̄il bin Ibrāhỉm bin al-Mughỉrah al-Ju'fiy al-.2006. Șaḥiḥ al-Bukhāriy, Riyāḍ: Maktabah al-Rusyd,

Djuned, Daniel. 2010. Ilmu Hadis: Paradigma Baru dan Rekonstruksi Ilmu Hadis, Jakarta: Erlangga,

'Itr, Nūr al-Dỉn. 1997. Manhaj al-Naqd fī 'Ulüm al-Hadìis, Sūriah: Dār al-Fikr Dimasyqi

Khațib, Muḥammad 'Ajāj al-.1989. Ușul al-Hadìis: 'Ulümuh wa Muṣtalaḥh, Beirut: Dār al-Fikr

Lestari, Lenni. 2012. Epistemologi Ilmu Asbab al-Wurud Hadis, Makalah, Tidak Diterbitkan,

Mudhofir, Ali dan Santoso, Heri. 2007. Asas Berfilsafat, Yogyakarta: Pustaka Rasmedia,

Munawwir, Ahmad W.1997. Kamus al-Munawwir Arab-Indonesia Terlengkap, Surabaya: Pustaka Progressif,

Muslim, Abū al-Ḥusain bin al-Ḥajjāj al-Qusyairiy al-Nisābūriy. 2006. Ṣahịh Muslim, Riyāḍ: Dār Tayyibah,

Mustaqim, Abdul. 2008. Ilmu Ma'anil Hadis: Paradigma Interkoneksi, Yogyakarta: Idea Press,

Naisābūrí, al-.1977. Ma 'rifät 'Ulüm al-Hadìis, Kairo: Maktabah al-Mutanabí,

Najjar, Zaghlul, al-. 2011. Sains dalam Islam: Mengungkap Fakta Ilmiah dari Kemukjizatan Hadis Nabi, terj. Amzah: Jakarta: tp,

Qutaibah, Ibn. 1995. Ta'wìl Mukhtalif al-Hadìis, Beirūt: Dār al-Kutub al'Ilmiyyah,

Rachman, Fathur. 1974. Ikhtisar Mushthalahul Hadis, Bandung: Al Ma’arif

Syāfi ‘i, al-.1986. Ikhtilāf al-Hạadìs, Beirūt: Dār Kutub al-'Ilmiyyah

Ṭaḥawī, Abū Ja'far al-, Musykil al-Aśar, Beirūt: Muassasah al-Risālah, 1994. 